\title{
Batrachochytrium dendrobatidis in amphibians of Cameroon, including first records for caecilians
}

\author{
T. M. Doherty-Bone ${ }^{1,2,9, *}$, N. L. Gonwouo ${ }^{3}$, M. Hirschfeld ${ }^{4}$, T. Ohst ${ }^{4}$, C. Weldon ${ }^{5}$, \\ M. Perkins ${ }^{2}$, M. T. Kouete ${ }^{3}$, R. K. Browne ${ }^{6}$, S. P. Loader ${ }^{1,7}{ }^{7}$, D. J. Gower ${ }^{1}$, M. W. Wilkinson ${ }^{1}$, \\ M. O. Rödel ${ }^{4}$, J. Penner ${ }^{4}$, M. F. Barej ${ }^{4}$, A. Schmitz ${ }^{8}$, J. Plötner ${ }^{4}$, A. A. Cunningham ${ }^{2}$ \\ ${ }^{1}$ Department of Life Sciences, The Natural History Museum, London, SW7 5BD, UK \\ ${ }^{2}$ Institute of Zoology, Zoological Society of London, Regents Park, London NW1 4RY, UK \\ ${ }^{3}$ Project CamHerp, BP 1616, Yaoundé, Cameroon \\ ${ }^{4}$ Museum für Naturkunde, Leibniz Institute for Research on Evolution and Biodiversity, Berlin 10115, Germany \\ ${ }^{5}$ Unit for Environmental Research: Zoology, North-West University, Potchefstroom 2520, South Africa \\ ${ }^{6}$ Royal Zoological Society of Antwerp, Koningin Astridplein 26, 2018 Antwerp, Belgium \\ ${ }^{7}$ University of Basel, Department of Environmental Sciences, Basel 4056, Switzerland \\ ${ }^{8}$ Department of Herpetology \& Ichthyology, Muséum d'histoire naturelle, Geneva 1208, Switzerland \\ ${ }^{9}$ Present address: School of Geography, University of Leeds, West Yorkshire, LS2 9JT, UK
}

\begin{abstract}
Amphibian chytrid fungus Batrachochytrium dendrobatidis $(B d)$ has been hypothesised to be an indigenous parasite of African amphibians. In Cameroon, however, previous surveys in one region (in the northwest) failed to detect this pathogen, despite the earliest African $B d$ having been recorded from a frog in eastern Cameroon, plus one recent record in the far southeast. To reconcile these contrasting results, we present survey data from 12 localities across 6 regions of Cameroon from anurans $(\mathrm{n}=1052)$ and caecilians $(\mathrm{n}=85)$ of ca. 108 species. $B d$ was detected in 124 amphibian hosts at 7 localities, including Mt. Oku, Mt. Cameroon, Mt. Manengouba and lowland localities in the centre and west of the country. None of the hosts were observed dead or dying. Infected amphibian hosts were not detected in other localities in the south and eastern rainforest belt. Infection occurred in both anurans and caecilians, making this the first reported case of infection in the latter order (Gymnophiona) of amphibians. There was no significant difference between prevalence and infection intensity in frogs and caecilians. We highlight the importance of taking into account the inhibition of diagnostic qPCR in studies on $B d$, based on all $B d$-positive hosts being undetected when screened without bovine serum albumin in the qPCR mix. The status of $B d$ as an indigenous, cosmopolitan amphibian parasite in Africa, including Cameroon, is supported by this work. Isolating and sequencing strains of $B d$ from Cameroon should now be a priority. Longitudinal host population monitoring will be required to determine the effects, if any, of the infection on amphibians in Cameroon.
\end{abstract}

KEY WORDS: Amphibian chytrid fungus $\cdot$ Real time PCR $\cdot$ Africa $\cdot$ PCR inhibition Resale or republication not permitted without written consent of the publisher

\section{INTRODUCTION}

The amphibian chytrid fungus Batrachochytrium dendrobatidis $(B d)$ has been implicated in recent, rapid and enigmatic declines of amphibians worldwide (Skerratt et al. 2007, Lötters et al. 2009, Craw- ford et al. 2010, Farrer et al. 2011). One hypothesis for the emergence of $B d$ is the introduction of infected Xenopus spp. from an endemic focus in Africa to other regions. This is supported by histological and molecular studies on archived Xenopus spp. in museum collections (Weldon et al. 2004, Soto-Azat 
et al. 2010), the export statistics of Xenopus spp. from South Africa (Weldon et al. 2007) and the occurrence of $B d$ in wild populations of anurans in multiple localities in southern, central and eastern Africa with no apparent impact on the host populations (Hopkins \& Channing 2003, Goldberg et al. 2007, Greenbaum et al. 2008, Kielgast et al. 2010, Bell et al. 2011). It has therefore been hypothesised that $B d$ is an indigenous, endemic parasite of amphibians on the African continent.

The results of recent surveys of amphibians in northwest Cameroon challenged this hypothesis, with a representative sample of amphibians failing to show infection of $B d$ using sensitive molecular techniques (Mount Oku: Doherty-Bone et al. 2008; Mt. Fungom: Baláž et al. 2012). An analysis of the world's anurans found that 19 species restricted to Cameroon and the Biafran Highlands possessed biological traits that make them susceptible to decline caused by $B d$ infection (Bielby et al. 2008), and it has been proposed that amphibians restricted to the highlands of Cameroon are at risk from the incursion of $B d$ from neighbouring infected regions (Doherty-Bone et al. 2008, Baláž et al. 2012). Cameroon has at least 200 species of amphibian (Amiet 2008), with 57 endemic to the country (predominately found in highland areas) and 63 listed as threatened with extinction (IUCN 2012). The discovery of new species of Phrynobatrachus and Petropedetes across Cameroon (Zimkus 2009, Barej et al. 2010, Rödel et al. 2012) highlights the strong likelihood that many additional cryptic, endemic species remain undescribed.
$B d$ was detected in an archived Xenopus fraseri collected in 1933 in the lowlands of Cameroon, ca. $300 \mathrm{~km}$ from Mt. Oku (Soto-Azat et al. 2010), a single reed frog Phlyctimantis leonardi from the extreme southeast of Cameroon (Baláž et al. 2012), from recent surveys of frogs in the Okoumo National Park (Imasuen et al. 2011) and Gashaka-Gumti National Park, Nigeria (Reeder et al. 2011), and from 2 localities in Gabon (Bell et al. 2011). These contradictory results (one very old record versus no recent detection of $B d$ from Cameroon despite records in surrounding countries and one very recent record in a peripheral locality) led us to conduct additional $B d$ surveillance across a wider area of Cameroon to better assess the current distribution of this pathogen and prevalence across taxonomic groups.

\section{MATERIALS AND METHODS}

Field work took place in 11 locations throughout Cameroon from 2007 to 2011 (Table 1). Six of the sample sites were in mountain bioclimatic zones, one in the southern Cameroon plateau zone and 5 in the lowland rainforest zone (Fig. 1). Sampling took place during the wet seasons of 2007 to 2011, the transition of wet season to dry season in 2008 and the beginning of the wet season in 2009 (for a review of climate and general seasonal weather patterns in Cameroon, see Molua 2006). Habitats comprised small-holder cultivated land (all localities), intensive rubber plantation (Mundame), lowland rainforest

Table 1. Sample localities and techniques for $B d$ across Cameroon. Dates are given as dd/mm/yyyy

\begin{tabular}{|c|c|c|c|c|c|c|}
\hline Region & Locality & Bioclimatic zone & $\begin{array}{l}\text { Sampling } \\
\text { technique(s) }\end{array}$ & $\begin{array}{l}\text { Elevation } \\
\quad(\mathrm{m})\end{array}$ & From & To \\
\hline Centre & Ndikiniméki & $\begin{array}{l}\text { Southern Cameroon } \\
\text { plateau }\end{array}$ & Swab & $797-831$ & $19 / 11 / 2008$ & $20 / 11 / 2008$ \\
\hline East & Doumo-Pierre & Lowland rainforest & Swab & 650 & $25 / 04 / 2009$ & $04 / 05 / 2009$ \\
\hline Littoral & Ebo Forest & Lowland rainforest & Swab & $102-921$ & 08/01/2011 & $31 / 10 / 2011$ \\
\hline $\begin{array}{l}\text { Littoral \& } \\
\quad \text { Southwest }\end{array}$ & Mt. Manengouba & Mountain & $\begin{array}{l}\text { Swab and toe clip } \\
\text { Swab }\end{array}$ & $\begin{array}{c}1000-2200 \\
996-2242\end{array}$ & $\begin{array}{c}\text { August } 2007 \\
12 / 09 / 2011\end{array}$ & $\begin{array}{l}\text { July } 2008 \\
21 / 10 / 2011\end{array}$ \\
\hline Northwest & Mt. Oku & Mountain & $\begin{array}{l}\text { Swab and inter- } \\
\text { dental brush }\end{array}$ & $1793-2200$ & $10 / 10 / 2008$ & $30 / 05 / 2009$ \\
\hline \multirow[t]{5}{*}{ Southwest } & Mundame & Lowland rainforest & Swab & $33-89$ & $22 / 11 / 2008$ & $22 / 11 / 2008$ \\
\hline & Banga Bakundu & Lowland rainforest & Swab & 56 & $23 / 11 / 2008$ & $23 / 11 / 2008$ \\
\hline & Mt. Cameroon & Mountain & Swab & $1374-1450$ & $24 / 11 / 2008$ & $24 / 11 / 2008$ \\
\hline & Mt. Kupe & Mountain & Toe clip & 950 & 05/07/2009 & 07/07/2009 \\
\hline & Rumpi Hills & Mountain & $\begin{array}{l}\text { Toe clip and inter- } \\
\text { dental brush }\end{array}$ & $315-1700$ & 08/07/2009 & $17 / 07 / 2009$ \\
\hline South & Campo & Lowland rainforest & $\begin{array}{l}\text { Toe clip and inter- } \\
\text { dental brush }\end{array}$ & $50-150$ & $23 / 10 / 2007$ & $10 / 11 / 2007$ \\
\hline West & Dschang & Mountain & Swab & 787 & $26 / 11 / 2008$ & $26 / 11 / 2008$ \\
\hline
\end{tabular}




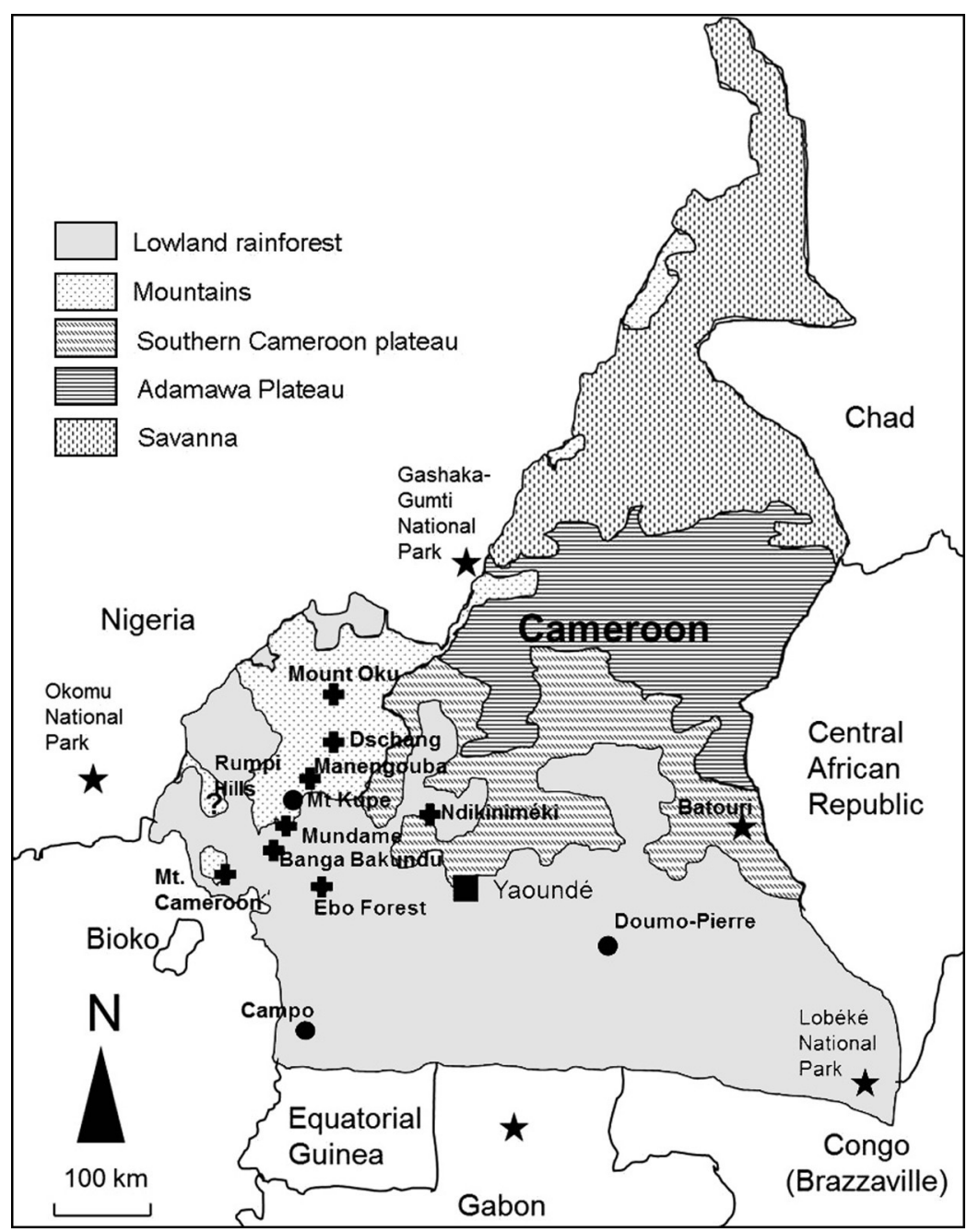

Fig. 1. Positive (crosses) and negative (dots) localities for Batrachochytrium dendrobatidis $(B d)$ in Cameroon. The 5 stars highlight published positive records for Bd: Gabon, Okomu National Park, Gashaka-Gumti National Park, Lobéké National Park and Batouri (see 'Introduction' for details). The '?' indicates the uncertain diagnosis for a single specimen of Phrynobatrachus cf. sandersoni. Layers show bioclimatic zones, adapted from Amiet (2008)

the mountain zone (Northwest, Southwest and West Regions) (see Table S1 in the supplement, available at www. int-res.com/articles/suppl/d102p181_ supp.pdf). In total, 1137 samples (1052 anurans, 85 caecilians) from at least 108 species (104 anuran, 4 caecilian) were screened for the presence of $B d$ (Table S1).

Sampling protocols varied because different field teams were operating with different resources and priorities (Table 1). Anurans from Mt. Oku, Doumo-Pierre, Ebo Forest, Mt. Manengouba, Mundame, Mt. Cameroon and Ndikiniméki (699 out of 1052 specimens in total) were sampled for $B d$ infection by swabbing the skin over the pelvic patch, ventral surface of each thigh and plantar surface of each hind foot using a sterile fine-tipped rayon swab (MW100-100; Medical Wire \& Equipment Co). The procedure for sampling tadpoles was restricted to swabbing of the keratinized mouthparts. Each caecilian was skinswabbed along the length of most of the body on the dorsal, lateral and ventral surfaces. Each of 3 caecilians collected in the Rumpi Hills was euthanased with an overdose of tricaine methane sulphonate (MS-222, Thomson \& Joseph), and a small piece of dorsal skin was removed one-third from the anterior tip of the body and stored in ethanol. Because caecilians are typically covered in soil following collection, and as soil often contains inhibitors of the PCR reaction (Hyatt

(Doumo-Pierre, Ebo Forest, Big Massaka on the foot of Rumpi Hills, Campo) and montane forest and grassland (Rumpi Hills and Mts. Cameroon, Kupe, Manengouba and Oku). Anurans were caught by hand during either visual encounter surveys or opportunistically during other field work. Aquatic anurans and tadpoles were captured using hand nets or aquatic funnel traps. Caecilians were captured during dedicated digging surveys or were presented by members of local communities.

The numbers of specimens sampled were as follows: 74 in the southern Cameroon plateau zone (Central Region); 310 in the lowland rainforest zone (East, Littoral, South and Southwest Regions); 753 in et al. 2007) and potentially $B d$ zoospores (Johnson \& Speare 2005), all specimens were rinsed in clear, locally sourced water prior to sampling. Similarly, many anurans were also rinsed prior to skin-swabbing. Following sampling, the tip of each swab was either stored dry within an individual plastic sleeve and kept cool and out of direct sun, or was placed in a $1.5 \mathrm{ml}$ vial containing $95 \%$ high-grade ethanol to prevent degradation of DNA by the tropical heat (Van Sluys et al. 2008) prior to shipment to the laboratory.

Cross-contamination between specimens was minimised by wearing surgical gloves between specimens, using new or disinfected specimen containers to hold animals prior to swabbing and swabbing 
specimens prior to opportunities for cross-contamination, such as being placed in MS-222 potentially contaminated by infected specimens (Webb et al. 2005). There was a small risk of cross-contamination of zoospores between animals caught in succession in the field, but this was diminished by $B d$ not surviving longer than 6 min on human hands (Mendez et al. 2008) and by the rinsing procedure described above. To prevent spreading $B d$ zoospores between sample sites, all equipment, including boots and specimen bags, was cleaned, disinfected with bleach and/or dried in the sun.

Other anurans were sampled for $B d$ using toe-clips in part because of a shortage of swabs and partly because they were being collected for genetic studies. Toe-clips were collected from anurans at Campo (85 out of 130 amphibians), Mt. Kupe (all 82 amphibians captured), Mt. Manengouba (123 out of 357 amphibians) and Rumpi Hills (141 out of 144 amphibians). Toe-clips were fixed and stored in 95\% ethanol. Forty-nine Xenopus longipes and 45 specimens from Campo were not skin-swabbed in the field, but were euthanased with an overdose of MS222 and fixed and stored in 95\% high grade ethanol. Upon return to the laboratory, the skin of each of these alcohol-fixed animals was sampled for $B d$ DNA using an inter-dental brush as described by SotoAzat et al. (2009). Fifteen ethanol-preserved Phrynobatrachus voucher specimens collected from the Rumpi Hills that had already been toe-clipped were re-sampled in the laboratory using inter-dental brushes (see Results and Discussion). To reassess the presence of $B d$ on $\mathrm{Mt}$. Oku in previous years, we repeated diagnostic qPCR assay for DNA extracts that had been collected from 212 anurans (toe-clips) and one caecilian (skin scrape taken using a sterile scalpel) from Mt. Oku in 2006. These were previously found to yield $B d$-negative results (Doherty-Bone et al. 2008). The previous sample size (283 individuals) included 71 DNA samples that were used up in the original laboratory analysis. Originally, these samples had been screened without bovine serum albumin (BSA) to reduce PCR inhibition, potentially concealing Bd-positive samples (Garland et al. 2010).

Samples (total of 1137) were screened at the laboratories of the Institute of Zoology, London (IoZ; 645 samples), the Museum für Naturkunde, Berlin (MfN; 325 samples), and the National Zoological Garden, Pretoria (NZG; 167 samples). In the laboratory, DNA was extracted, diluted to 1/10 and analysed using qPCR according to the protocol of Boyle et al. (2004). For samples processed at MfN, DNA clean-up was achieved with a QIAquick PCR Purifi- cation Kit (Qiagen) for swabs and a Qiagen DNeasy kit for toe-clips, following the manufacturer's instructions. All DNA extracts and dilutions were stored at $-80^{\circ} \mathrm{C}$ prior to analysis using PCR. At MfN, a TaqMan probe was used that was not conjugated with an MGB protein but included LNA bases to elevate the melting temperature (5'-6FAMCGA GTC+G+AA+ C+ $\left.\mathrm{A}+\mathrm{A}+\mathrm{AAT} \mathrm{BBQ}-3^{\prime}\right)$. At $\mathrm{MfN}, \mathrm{qPCR}$ reactions were performed in a final volume of $20 \mu$ leither on a LightCycler 2.0 or on a LightCycler 480 (both Roche Applied Science). Reaction mixtures at MfN contained $0.25 \mu \mathrm{M}$ of each primer, $62.5 \mu \mathrm{M}$ of each $\mathrm{dNTP}, 1.5 \mathrm{mM} \mathrm{MgCl} 2,6 \% \mathrm{BSA}, 2 \mu \mathrm{l}$ of $10 \times$ reaction buffer (BD, Solis BioDyne), 1 unit Taq DNA polymerase (AmpliTaq, ABI) and $1 \mu \mathrm{l}$ DNA. Cycling profile at MfN consisted of an initial denaturation step at $96^{\circ} \mathrm{C}$ for $5 \mathrm{~min}$, followed by 50 cycles of $10 \mathrm{~s}$ at $96^{\circ} \mathrm{C}$ and $1 \mathrm{~min}$ at $60^{\circ} \mathrm{C}$. At the IoZ, samples were retrospectively found to show inhibition (1 in 50 randomly selected samples) when screened with internal positive controls. Thus, all samples were rescreened with BSA added to the PCR mix to reduce inhibition (Garland et al. 2010). At all laboratories, samples were run with standards of known zoospore concentration and a negative control simultaneously included in the diagnostic assay. A positive result consisted of a clearly sigmoid curve in both replicated samples. If only a single well showed amplification, the PCR assay was repeated in duplicate for that sample and only if the repeat showed clear positivity in both wells was the sample deemed to be positive.

\section{RESULTS}

In total, 124 samples were positive for $B d$, with an overall prevalence of $10.9 \%$ (with a $95 \% \mathrm{CI}$ of $9-13 \%)$, a mean prevalence per locality of $32.0 \%$ and a median prevalence per locality of $12.9 \pm$ 36.7 (SD)\%. Positive localities included BangaBakundu (100\% prevalence, with $100 \%$ CI), Dschang (80\%; 45-115\% CI), Ebo Forest (2.5\%; 0-7\% CI), Mt. Cameroon $(60 \%$; 17-103\% CI), Mt. Manengouba $(6.4 \% ; 4-9 \%$ CI), Mt. Oku (19\%; 13-25\% CI), Mundame (57\%; 36-78\% CI) and Ndikiniméki (58\%; 47-69\% CI). No positive rtPCR amplifications occurred for samples collected in Doumo-Pierre ( $\mathrm{n}=$ 122), Campo $(\mathrm{n}=130)$ or Mt. Kupe $(\mathrm{n}=82)$. A single DNA extract from a swabbed Phrynobatrachus cf. sandersoni collected from the Rumpi Hills was found to be positive (genomic equivalent, GE, of 5 to 10 zoospores) at MfN. The ethanol-fixed specimen corresponding to this sample, along with all other 
Phrynobatrachus specimens collected in the vicinity of the Rumpi Hills were rescreened at the IoZ using the inter-dental brush technique, and were negative for $B d$. All 212 DNA extracts originating from Mt. Oku in 2006 were negative for $B d$ when subjected to diagnostic qPCR assay with BSA. Infection intensity was generally low for all $B d$-positive specimens sampled, with a mean zoospore GE of 3.82, and a median of $1.67 \pm 8.40$. The highest GE value was 85.54 zoospores for a Cardioglossa gracilis from Mt. Manengouba, with the highest GE value for a caecilian being 17.34 zoospores for a Herpele squalostoma from Ndikiniméki.

A total of 71 out of 1052 anurans $(6.7 \%)$ and 53 out of 85 caecilians $(62.4 \%)$ were positive for $B d$. Comparing anurans with caecilians across Cameroon, infection intensity was marginally significantly different (Mann-Whitney $\mathrm{p}=0.052$ ) with a higher median $(\mathrm{GE}=1.84)$ but lower mean $(\mathrm{GE}=3.37)$ in caecilians, compared to a higher mean (GE $=4.48$ ) but lower median $(\mathrm{GE}=0.89)$ in anurans. For localities where both caecilians and anurans were sampled (Mt. Oku, Mundame, Ndikiniméki), prevalence varied from being higher (Mt. Oku, Ndikiniméki) to being lower in caecilians than in anurans (Mundame; Table 2). Parasite loads in these localities also ranged from being higher in caecilians than anurans (Ndikiniméki), to being lower in caecilians (Mt. Oku, Mundame), although none of these differences was significant (Mann-Whitney $U$, Mt. Oku: $\mathrm{p}=0.63$; Mundame: $\mathrm{p}=$ 1.00; Ndikiniméki: $p=0.29$, Table 2 ). In the only locality (Ndikiniméki) where multiple species of both caecilians and anurans were swabbed, prevalence was not significantly different (Mann-Whitney $\mathrm{p}=0.49$ ).

\section{DISCUSSION}

We tested 1137 amphibians from 12 locations across Cameroon for evidence of infection with $B d$, of which 177 individuals were positive at 7 of those localities. An additional Bd-positive locality in Cameroon has also recently been discovered at Lobéké National Park (South Region near the CongoBrazzaville border) with a prevalence of $1.4 \%$ (Baláž et al. 2012). One positive $B d$ PCR result from a toeclip of Phrynobatrachus of. sandersoni from the Rumpi Hills is possibly the result of post-sampling contamination, as this specimen was negative for $B d$ when re-sampled using an inter-dental brush. There is, however, a possibility that $B d$ DNA was present and diluted by storage in ethanol, preventing detection following re-sampling.

All localities where $B d$ was undetected had a sample-size exceeding 59 individuals (Campo, $\mathrm{n}=130$; Doumo-Pierre, $\mathrm{n}=112$; Mt. Kupe, $\mathrm{n}=82$; the Rumpi Hills, $\mathrm{n}=144$ ). Ignoring false negatives, this is sufficient for a probability of at least 0.95 of detecting a $5 \%$ prevalence of $B d$ infection (DiGiacomo \& Koepsell 1986, Thrusfield 1995, Kriger et al. 2006). This assumes that all amphibians tested at each of these localities have an equal probability of being infected with $B d$, should it be present. False negatives could have occurred if the $B d$ DNA had become degraded (Van Sluys et al. 2008, Soto-Azat et al. 2009) or due to the presence of PCR inhibitors (Hyatt et al. 2007). Most of the samples were fixed in ethanol, and amphibian DNA has since been successfully extracted from multiple tissue samples fixed and stored in the same batch of ethanol used to preserve the diagnostic samples. Interference by PCR inhibitors should have been minimised by the addition of BSA in most (970 out of 1137) of the PCR reactions. In the IoZ, all $B d$-positive samples were negative prior to the assay being repeated with BSA, demonstrating the importance of using BSA when using qPCR to diagnose $B d$. The sample of Baláž et al. (2012) may also reveal additional positives for the 2 localities sampled if rescreened using BSA.

The hypothesis that Cameroon, or at least Mt. Oku, is a $B d$ sink (Doherty-Bone et al. 2008) is not necessarily disproved by this study. Despite showing $21 \%$

Table 2. Comparisons of infection of Batrachochytrium dendrobatidis $(B d)$ for sympatric anuran and caecilian amphibians. GE: genomic equivalents

\begin{tabular}{|c|c|c|c|c|c|c|c|c|}
\hline & & \multirow{2}{*}{$\begin{array}{c}\text { No. species } \\
\text { sampled }\end{array}$} & \multirow{2}{*}{$\begin{array}{l}\text { No. specimens } \\
\text { sampled }\end{array}$} & \multirow{2}{*}{$\begin{array}{l}\text { No. } B d \\
\text { positive }\end{array}$} & \multirow{2}{*}{$\begin{array}{c}\text { Prevalence } \\
(95 \% \text { CI })\end{array}$} & \multicolumn{3}{|c|}{ - GE - } \\
\hline & & & & & & Mean & Median & $\mathrm{SD}$ \\
\hline \multirow[t]{2}{*}{ Mt. Oku } & Caecilians & 1 & 5 & 4 & $0.80(0.45-1.15)$ & 3.14 & 3.14 & 4.34 \\
\hline & Anurans & 11 & 144 & 27 & $0.19(0.12-0.25)$ & 4.26 & 2.83 & 3.80 \\
\hline \multirow[t]{2}{*}{ Mundame } & Caecilians & 1 & 19 & 10 & $0.53(0.30-0.75)$ & 2.67 & 2.07 & 1.35 \\
\hline & Anurans & 2 & 2 & 2 & $1.00(1.00)$ & 5.56 & 5.56 & 6.36 \\
\hline \multirow[t]{2}{*}{ Ndikiniméki } & Caecilians & 3 & 43 & 28 & $0.65(0.51-0.79)$ & 3.15 & 1.79 & 4.49 \\
\hline & Anurans & 10 & 31 & 15 & $0.48(0.31-0.66)$ & 2.09 & 0.71 & 2.53 \\
\hline
\end{tabular}


prevalence (95\% CI: $15-28 \%)$ during the late wet season of 2008, Mt. Oku showed between-year variation in $B d$ prevalence. The sample from the 2006 peak wet season remained $B d$ negative after being retested with BSA. All anurans sampled on Mt. Oku in the early wet season of 2009 were $B d$ negative, although this was a small sample $(\mathrm{n}=16)$. Assessing whether $B d$ has an indigenous host range in Mt. Oku has already received some, albeit limited, research attention through the sampling of archived museum Pipidae from this locality (44 Xenopus longipes; SotoAzat et al. 2010). This sample has the advantage of being fixed in ethanol rather than formalin by the collector (M. E. Gartshore pers. comm.), reducing the likelihood that pathogenic DNA was undetected by qPCR had it been present (see Soto-Azat et al. 2009). $X$. longipes was not found to be infected with $B d$ in this study despite being sympatric with infected frogs of other species, suggesting this may not be a suitable focal species for the monitoring of $B d$ on Mt. Oku.

The failure to detect $B d$ in southern and eastern Cameroon (Campo and Doumo-Pierre) contrasts with reported $B d$ infection in a Xenopus fraseri specimen collected from the east of the country (Soto-Azat et al. 2010) and an infected Phlyctimantis leonardi found in the southeast (Baláž et al. 2012). This is despite these localities and Mt. Kupe having similar climates and no apparent geographic barrier to $B d$-positive localities. Whether or not it is established that $B d$ has an historical, indigenous host range in Cameroon, longitudinal sampling of regional amphibian assemblages could provide insights into seasonal fluctuations of $B d$-host interactions, including host population cycles in response to parasite load. This would also provide the means to assess cause-effect influences of $B d$ on amphibian assemblages in Cameroon, particularly where $B d$ has not yet been detected. Understanding such interactions could prove useful in understanding the management of $B d$ in other regions, including where it has caused amphibian declines.

This is the first published record of caecilians being infected with $B d$. As in many other areas of their biology, caecilians have been under-researched with respect to $B d$ (Gower \& Wilkinson 2005). To our knowledge, this is the largest sample of caecilians tested for $B d$ infection to date, and it reveals negligible differences between sympatric anurans and caecilians in both prevalence and parasite load, something that merits investigation in other areas such as East Africa and Latin America where $B d$ is reported in anurans but sympatric caecilians have not been investigated. Our infection data from caecilians demonstrates the non-specific nature of $B d$ to potentially infect any amphibian host. The isolation, histology and genomic sequencing of $B d$ originating from caecilians will help establish whether this strain is the same as that infecting anurans, or whether it is a strain specific to caecilian amphibians. The strain will at least be similar to those strains known from other amphibians detectable by the qPCR assay of Boyle et al. (2004), as opposed to Asian varieties of this fungus (i.e. Goka et al. 2009). Where $B d$ has caused declines of anurans, no data are available on population trends or the health of sympatric caecilians, although methods for quantitatively surveying caecilians have been developed in recent years (e.g. Measey et al. 2003, Gower et al. 2004, Measey 2006, Doherty-Bone et al. 2011).

Understanding the current geographical distribution of $B d$ infection of amphibians is necessary for conservation planning because this information allows the identification of regions where the fungus is absent or regions where it is endemic and may act as a source of spread (Skerratt et al. 2007). Cameroon now represents the latter, although the interaction of this pathogen with its hosts, many of which are of conservation concern, is so far not understood amidst a paucity of data on amphibian populations, typical of most African countries south of the Sahara (Lawson \& Klemens 2001). Because we found 2 amphibian assemblages of particular conservation concern (Mt. Kupe, Rumpi Hills) to be free of $B d$ infection, the possibility exists that these populations would be threatened by the spread of $B d$ from the surrounding lowlands. These and other sites should be placed under surveillance in these and other areas of important amphibian diversity (e.g. Mt. Oku, Mt. Tchabal Mbabo) to alert conservationists of the spread and likely incursion of $B d$. Such a dedicated surveillance programme would require periodic sampling, possibly yearly during the wet season. Ascertaining the identity of this strain of $B d$ through genomic sequencing will help assess its origin, virulence and threat to amphibians in Cameroon and elsewhere (Farrer et al. 2011). The impact of $B d$ in the conservation management of Cameroon's amphibians remains uncertain.

Acknowledgements. We thank the 2 anonymous reviewers who commented on this manuscript. Permits for research and export of samples were provided by the Cameroon Ministry of Forests and Wildlife to T.M.D.B. (no. 0928), M.H. (no. 1015), M.F.B. (no. 0057) and N.L.G. (no. 0602). Field and lab work was funded by grants to T.M.D.B. from the Percy Sladen Memorial Grant of the Linnean Society, Erasmus Darwin Barlow Grant from the Zoological Society of London, 
Small Ecological Project Grant from the British Ecological Society, Royal Zoological Society of Scotland, Natural History Museum, London, and the Institute of Zoology, London; grants to M.F.B. from the German Academic Exchange Service (DAAD) and the Alexander Koenig Stiftung, Bonn; and grants to N.L.G. from Conservation International and Rufford Small Grants. M.H. was supported by an Elsa-Neumann-scholarship, the DAAD and MfN funds. Analysis of Manengouba, Kupe, and Rumpi samples was within a project of the German Science Foundation (DFG PL 213/6-1). D. Dalton from the National Zoological Gardens, Pretoria, provided molecular analysis of some of the samples. We thank R. Ndifon, D. Ndifon, O. Nyingchia, H. Kolem, K. Peter, Y.F. Talah, D. Fotibu, K. Garrett, P. Janzen, M. Dahmen, N. Tagg, M. LeBreton, J.A.M. Barej and members of the many communities for assistance in the field and elsewhere.

\section{LITERATURE CITED}

Amiet JL (2008) Frog biodiversity in Cameroon. In: Stuart SN, Hoffmann M, Chanson JS, Cox NA, Berridge RJ, Ramani P, Young BE (eds) Threatened amphibians of the world. Lynx Edicions with IUCN - The World Conservation Union, Conservation International and NatureServe, Barcelona, p 61

Baláž V, Kopecký O, Gvoždík V (2012) Presence of the amphibian chytrid pathogen confirmed in Cameroon. Herpetol J 22:191-194

Barej MF, Rödel MO, Gonwouo LN, Pauwels OSG, Böhme W, Schmitz A (2010) Review of the genus Petropedetes Reichenow, 1874 in Central Africa with the description of three new species (Amphibia: Anura: Petropedetidae). Zootaxa 2340:1-49

Bell RC, Garcia AVG, Stuart BL, Zamudio KR (2011) High prelevance of the amphibian chytrid pathogen in Gabon. EcoHealth 8:116-120

Bielby J, Cooper N, Cunningham AA, Garner TJ, Purvis A (2008) Predicting susceptibility to future declines in the world's frogs. Conserv Lett 1:82-90

Boyle DG, Boyle DP, Olsen V, Morgan JAT, Hyatt AD (2004) Rapid quantitative detection of chytridiomycosis (Batrachochytrium dendrobatidis) in amphibian samples using real-time Taqman PCR assay. Dis Aquat Org 60:141-148

> Crawford AJ, Lips KR, Bermingham E (2010) Epidemic disease decimates amphibian abundance, species diversity, and evolutionary history in the highlands of central Panama. Proc Natl Acad Sci USA 107:13777-13782

> DiGiacomo RF, Koepsell TD (1986) Sampling for detection of infection or disease in animal populations. J Am Vet Med Assoc 189:22-23

Doherty-Bone TM, Bielby J, Gonwouo NL, LeBreton M, Cunningham AA (2008) In a vulnerable position? Preliminary survey work fails to detect the amphibian chytrid pathogen in the Highlands of Cameroon, an amphibian hotspot. Herpetol J 18:115-118

> Doherty-Bone TM, Ndifon RK, San Mauro D, Wilkinson M, Gonwouo NL, Gower DJ (2011) Systematics and ecology of the caecilian Crotaphatrema lamottei (Nussbaum) (Amphibia: Gymnophiona: Scolecomorphidae). J Nat Hist 45:827-841

Farrer RA, Weinert LA, Bielby J, Garner TWJ and others (2011) Multiple emergences of genetically diverse amphibian-infecting chytrids include a globalized hyper- virulent recombinant lineage. Proc Natl Acad Sci USA 108:18732-18736

Garland S, Baker A, Phillott AD, Skerratt LF (2010) BSA reduces inhibition in a TaqMan ${ }^{\circledR}$ assay for the detection of Batrachochytrium dendrobatidis. Dis Aquat Org 92: 113-116

> Goka K, Yokoyama J, Une Y, Kuroki T and others (2009) Amphibian chytridiomycosis in Japan: distribution, haplotypes and possible route of entry into Japan. Mol Ecol 18:4757-4774

Goldberg TL, Readel AM, Lee MH (2007) Chytrid fungus in frogs from an equatorial African montane forest in western Uganda. J Wildl Dis 43:521-524

Gower DJ, Loader SP, Moncrieff CB, Wilkinson M (2004) Niche separation and comparative abundance of Boulengerula boulengeri and Scolecomorphus vittatus (Amphibia: Gymnophiona) in an East Usambara forest, Tanzania. Afr J Herpetol 53:183-190

> Gower DJ, Wilkinson M (2005) Conservation biology of caecilian amphibians. Conserv Biol 19:45-55

Greenbaum E, Kusamba C, Aristote MM, Reed K (2008) Amphibian chytrid fungus infections in Hyperolius (Anura: Hyperoliidae) from Eastern Democratic Republic of Congo. Herpetol Rev 39:70-73

Hopkins S, Channing A (2003) Chytrid fungus in Northern and Western Cape frog populations, South Africa. Herpetol Rev 34:334-336

> Hyatt AD, Boyle DG, Olsen V, Boyle DB and others (2007) Diagnostic assays and sampling protocols for the detection of Batrachochytrium dendrobatidis. Dis Aquat Org 73:175-192

Imasuen AA, Aisien MSO, Weldon C, Dalton DL, Kotze A, du Preez LH (2011) Occurrence of Batrachochytrium dendrobatidis in amphibian populations of Okomu National Park, Nigeria. Herpetol Rev 42:379-382

IUCN (International Union for the Conservation of Nature) (2012) IUCN Red List of Threatened Species. Version 2010.2. Available at www.iucnredlist.org (accessed 29 July 2012)

Johnson ML, Speare R (2005) Possible modes of dissemination of the amphibian chytrid Batrachochytrium dendrobatidis in the environment. Dis Aquat Org 65: 181-186

Kielgast J, Rödder D, Veith M, Lötters S (2010) Widespread occurrence of the amphibian chytrid fungus in Kenya. Anim Conserv 13(Suppl s1):36-43

Kriger KM, Hines HB, Hyatt AD, Boyle DG, Hero JM (2006) Techniques for detecting chytridiomycosis in wild frogs: comparing histology with real-time Taqman PCR. Dis Aquat Org 71:141-148

Lawson DP, Klemens W (2001) Herpetofauna of the African rain forest: overview and recommendations for conservation. In: Weber W, White LJT, Naughton-Treves L (eds) African rainforest ecology and conservation. Yale University Press, New Haven, CT, p 291-307

> Lötters S, Kielgast J, Bielby J, Schmidtlein S and others (2009) The link between rapid enigmatic amphibian decline and the globally emerging chytrid fungus. EcoHealth 6:358-372

> Measey GJ (2006) Surveying biodiversity of soil herpetofauna: towards a standard quantitative methodology. Eur J Soil Biol 42:S103-S110

Measey GJ, Gower DJ, Oommen OV, Wilkinson M (2003) Quantitative surveying of endogeic limbless vertebrates - a case study of Gegeneophis ramaswamii (Amphi- 
bia: Gymnophiona: Caeciliidae) in southern India. Appl Soil Ecol 23:43-53

Mendez D, Webb R, Berger L, Speare R (2008) Survival of the amphibian chytrid fungus Batrachochytrium dendrobatidis on bare hands and gloves: hygiene implications for amphibian handling. Dis Aquat Org 82:97-104

Molua EL (2006) Climatic trends in Cameroon: implications for agricultural management. Clim Res 30:255-262

Reeder NMM, Cheng TL, Vredenburg VT, Blackburn DC (2011) Survey of the chytrid fungus Batrachochytrium dendrobatidis from montane and lowland frogs in eastern Nigeria. Herpetol Notes 4:83-86

Rödel MO, Doherty-Bone T, Koute MT, Janzen P and others (2012) A new small Phrynobatrachus (Amphibia: Anura: Phrynobatrachidae) from southern Cameroon. Zootaxa 3431:56-68

Skerratt LF, Berger L, Speare R, Cashins S and others (2007) Spread of chytridiomycosis has caused the rapid global decline and extinction of frogs. EcoHealth 4:125-134

Soto-Azat C, Clarke BT, Fisher MC, Walker SF, Cunningham AA (2009) Non-invasive sampling methods for the detection of Batrachochytrium dendrobatidis in archived amphibians. Dis Aquat Org 84:163-166

Soto-Azat C, Clarke BT, Poynton JC, Cunningham AA (2010) Widespread historical presence of Batracho-

Editorial responsibility: Alex Hyatt,

Geelong, Victoria, Australia chytrium dendrobatidis in African pipid frogs. Divers Distrib 16:126-131

Thrusfield M (1995) Veterinary epidemiology, 2nd edn. Blackwell Science, Oxford, p 187-191

Van Sluys M, Kriger KM, Phillott AD, Campbell R, Skerratt LF, Hero JM (2008) Storage of samples at high temperatures reduces the amount of amphibian chytrid fungus Batrachochytrium dendrobatidis DNA detectable by PCR assay. Dis Aquat Org 81:93-97

Webb R, Berger L, Mendez D, Speare R (2005) MS-222 (tricaine methane sulfonate) does not kill the amphibian chytrid fungus Batrachochytrium dendrobatidis. Dis Aquat Org 68:89-90

Weldon C, du Preez LH, Hyatt AD, Muller R, Speare R (2004) Origin of the amphibian chytrid fungus. Emerg Infect Dis 10:2100-2105

Weldon C, de Villiers L, du Preez LH (2007) Quantification of the trade in Xenopus laevis from South Africa, with implications for biodiversity conservation. Afr J Herpetol 56:77-83

Zimkus BM (2009) Biogeographical analysis of Cameroonian puddle frogs and description of a new species of Phrynobatrachus (Anura: Phrynobatrachidae) endemic to Mount Oku, Cameroon. Zool J Linn Soc 157: 795-813

Submitted: July 30, 2012; Accepted: November 5, 2012 Proofs received from author(s): January 24, 2013 